\title{
Diversity and ecology of forest communities in Küre Mountains National Park of Turkey
}

\author{
Diversidad y ecología de las comunidades forestales \\ en el Parque Nacional de las Montañas de Küre de Turquía
}

\author{
Bilge Tunçkol a*, Necmi Aksoy b, Süleyman Çoban c, Hayati Zengin ${ }^{\text {b }}$ \\ *Corresponding author: ${ }^{a}$ Bartin University, Ulus Vocational School Department of Forestry, \\ 74600, Ulus, Bartin, Turkey, +90 0378501 1000, btunckol@bartin.edu.tr \\ ${ }^{b}$ Düzce University, Faculty of Forestry \& DUOF Herbarium Konuralp, Düzce, Turkey. \\ ${ }^{\mathrm{c}}$ Istanbul University-Cerrahpasa, Faculty of Forestry, Department of Silviculture, Istanbul, Turkey.
}

\begin{abstract}
SUMMARY
This study aimed at analyzing the diversity and ecological characteristics of forest associations (121 relevés classified under eight associations) in Küre Mountains National Park. Ordination analyses (DCA and CCA) and response curves were used to reveal ecological characteristics of vegetation using soil parameters ( $\mathrm{pH}$, electrical conductivity, sand, clay and dust content, soil moisture) and topographical variables (altitude, slope, potential direct incident radiation and heat load). Ecological conditions of communities were also tested using average Ellenberg indicator values (EIVs). Among forest associations, the highest species diversity was found in Phillyreo latifoliae-Pinetum brutiae and the lowest diversity in Hedero-Castanetum sativae, which had a dense Rhododendron ponticum shrub layer. However, Salicio-Platanetum orientale and Buxo sempervirens-Carpinetum betuli had the highest beta diversity since they harbored unique species composition. Conditional effects of altitude, slope, $\mathrm{pH}$ and electrical conductivity, soil dust and sand content, sandy-loam and loam soil types presented significant contributions in species composition. While Carpino-Quercetum petraeae was found on soil with high dust content having high $\mathrm{pH}$ and electrical conductivity values, Quercetum roburi-Aceretum campestri and Salicio-Platanetum orientale were related to soil with loam. Species responses to soil and topographical variables varied for most tree species. Light EIVs, which has a high positive correlation with potential direct incident radiation and heat load, related to Phillyreo latifoliae-Pinetum brutiae and Salicio-Platanetum orientale. Riverside forest communities differed from other communities in nutrient and humidity EIVs. However, EIVs did not show a good correlation with associated soil parameters such as soil moisture-humidity EIVs and soil pH-acidity EIVs.
\end{abstract}

Key words: ecological differentiation, forest vegetation, Küre Mountains National Park, Turkey.

\section{RESUMEN}

Este estudio tuvo como objetivo analizar la diversidad y características ecológicas de asociaciones forestales (121 registros clasificados en ocho asociaciones) en el Parque Nacional Montañas de Küre. Se utilizaron análisis de ordenación (DCA y CCA) y curvas de respuesta para revelar las características ecológicas de la vegetación, utilizando parámetros del suelo ( $\mathrm{pH}, \mathrm{CE}$, arena, contenido de arcilla y limo, humedad del suelo) y variables topográficas (altitud, pendiente, radiación incidente directa potencial y carga de calor). Las condiciones ecológicas de las comunidades también se probaron utilizando indicadores de Ellenberg (EIV). Entre las asociaciones forestales, la mayor diversidad de especies se encontró en Phillyreo latifoliae-Pinetum brutiae y la menor en Hedero-Castanetum sativae, que presentó densa capa de arbustos de Rhododendron ponticum. Salicio-Platanetum orientale y Buxo sempervirens-Carpinetum betuli tuvieron la mayor diversidad beta ya que albergaron una composición de especies única. Los efectos de la altitud, pendiente, $\mathrm{pH}$ y $\mathrm{CE}$, contenido de limo y arena del suelo y los tipos de suelo franco-arenoso y franco tuvieron contribuciones significativas en la composición de especies. Carpino-Quercetum petraeae se encontró en suelos con alto contenido de limo y valores altos de pH y CE; Quercetum roburi-Aceretum campestri y Salicio-Platanetum orientale se relacionaron con suelos francos. Las respuestas de las especies al suelo y las variables topográficas variaron para la mayoría de las especies de árboles. EIV pequeños, con alta correlación positiva con PDIR y carga térmica, se relacionaron con Phillyreo latifoliae-Pinetum brutiae y Salicio-Platanetum orientale. Las comunidades de bosques ribereños se diferenciaron de otras comunidades con EIV de nutrientes y humedad. Los EIV no mostraron buena correlación con parámetros del suelo, como EIV de humedad y humedad del suelo y EIV de pH y acidez del suelo.

Palabras clave: diferenciación ecológica, vegetación forestal, Parque Nacional Montañas de Küre, Turquía. 


\section{INTRODUCTION}

Since plant communities develop as a combination of all factors in environment, their classification will gather this ecological information (Mueller and Ellenberg 1974, Kent and Coker 1992). Therefore, plant communities are characterized by distinctive features such as species composition, species richness, the types of different growth forms, and plant biomass structure as a response to strong environmental gradients (Dwire et al. 2004). Such features of plant communities enable ecologists to make statements about prevailing environmental conditions since the overlap of ecological tolerances of many species is smaller than the ecological amplitude of a single species (Çoban 2016). This theory provides the basis for the use of bioindication, where species composition of a given community allows conclusions to be made about environment as surrogates for measured environmental variables (Jean-Claude and Eva 2003, Wamelink et al. 2005). One of the most widely used bioindication systems of primary environmental parameters in Central Europe is proposed by Ellenberg et al. (1992) who assigned 2726 Central European vascular plant species, with respect to moisture, soil nitrogen status, soil reaction, light regime, temperature and continentality (Schaffers and Sýkora 2000).

Sustainable management of specific forest types requires comprehensive knowledge about mixture combinations, growth relations among species, site conditions, climate factors, biological characteristics and competitive ability of species (Çoban and Özalp 2012). Measured environmental variables can explain only main ecological conditions along with altitudinal zones. However, detailed information about local climate and soil condition within each altitudinal zones would explain most part of compositional variation (Aksoy and Çoban 2017). Especially, forest regions that harbor many forest types with various tree species mixtures require specific forest management plans. Ecological differentiations of forest communities and dominant tree species of the regions with diverse forest structure can provide valuable information for further studies in nature conservation and management. At this point, Küre Mountains, which are among the richest mountains in the western Black Sea Region of Turkey in terms of flora and vegetation diversity, can provide data for revealing ecological characteristics and competition abilities of tree species. The main reasons for this richness are as follows: a variety of climates, topographical diversity with marked changes in ecological and geomorphological characteristics. Küre Mountains is the meeting place of Euro-Siberian, Mediterranean and Irano-Turanian phytogeographical regions. In the field, these can usually be easily recognized by their different vegetational aspects which reflect differences in climate. However, fundamental differences are based on floristic differences, including endemism. There are a number of major vegetation types in these phytogeographical regions as forest, maquis and steppe vegetation.
The main objective of this study is to analyze the ecological characteristics of forest communities and main tree species of Küre Mountains by using measured environmental variables and Ellenberg indicator values (EIVs). Thus, it was hypothesized that 1) diverse ecological characteristics will be reflected in high alpha and beta diversity, 2) topographical (altitude and slope) and derived variables (heat load and direct incident radiation) will significantly affect the variation in species composition, 3) soil characteristics and associated species indicator values (EIVs) will show correlation.

\section{METHODS}

Study area. The study area covered the Bartın section (19,000 ha) of Küre Mountains (37,753 ha). Küre Mountains are situated between Bartın River on the west and Kizllırmak River in the east. The altitude of the region varies between $50 \mathrm{~m}-1200 \mathrm{~m}$. Euro-Siberian, Mediterranean and Irano-Turanian influences are seen in the region (figure 1). Küre National Park was identified as one of the 100 Forest Hot Spots of Europe which should be protected (Blumer 2010). Küre Mountains had a diverse forest vegetation, which consisted of pure and/or mixed stands of Quercus robur L., Carpinus betulus L., Quercus petraea (Matt.) Liebl., Pinus nigra J.F. Arnold, Fagus orientalis Lipsky, Pinus sylvestris L. and Abies nordmanniana (Steven) Spach subsp. bornmuelleriana (Matff.) Coode et Cullen.

Soil types of the region are grey-brown podzolic soil and red-yellow podzolic soil. Bedrock is mostly limestone. The annual precipitation is about $1040.2 \mathrm{~mm}$ and mean annual temperature is $12.9^{\circ} \mathrm{C}$. The climate type of the region is classified as B2B1'rb4 by the Thornthwaite climate classification system, which translates as characterized by humid, mesothermal, no or a little water deficiency in summer, and under the effect of oceanic climate (Uz et al. 2001, Şengönül et al. 2009, Ekici 2012, Göncüoğlu et al. 2015).

Methods. The vegetation was collected between 20142017 and classified according to Braun-Blanquet method (Braun-Blanquet 1932). Sizes of the relevés varied between $100-400 \mathrm{~m}^{2}$. Eight associations belonging to forest vegetation (a total of 121 relevés and 245 plant taxa) were determined (Tunçkol 2017). A total of six soil samples were taken from the sites representing each association. Two sets of soil samples were taken from the depths of 0-10 and 10-20 $\mathrm{cm}$ using $114 \mathrm{~cm}^{3}$ core sampler (AMS Soil Core Sampler). Soil samples (weighing about $2 \mathrm{~kg}$ ) were air dried and sieved $(<2 \mathrm{~mm}$ ) for analyses. Soil particlesize distribution was analyzed with a Bouyoucos hydrometer method, thus enabling soil texture determination (Gee and Bauder 1986). Soil pH and electrical conductivity (EC) were measured using a digital $\mathrm{pH}$ meter (Thomas 1996) and an electrical conductivity meter (Rhoades 1996) in a soil and water suspension (Hanna instruments HI 255 $\mathrm{pH} / \mathrm{EC}$ Meter). 
Ellenberg Indicator Values (EIVs) (Ellenberg et al. 1992, Pignatti et al. 2001) were assigned to species data and an average EIVs weighted by species cover was calculated for each relevé under JUICE (Tichy and Holt 2006). Shannon alpha diversity index and average Whittaker beta diversity $(\beta \mathrm{w}=\mathrm{S} / \alpha-1, \mathrm{~S}$ : total number of species, $\alpha$ : average number of species in each unit) were calculated for each relevé under JUICE. Soil parameters $(\mathrm{pH}$, soil electrical conductivity, sand, clay and dust content, soil moisture) and topographical variables (altitude, slope, potential direct incident radiation and heat load) were used in the analysis as measured variables. The potential direct incident radiation and heat load were calculated with the equations of McCune and Keon (2002).

For performing the multivariate analysis, Braun-Blanquet cover values were transformed into percentage values (r: 1\%, +: $2 \%, 1: 3 \%, 2: 13 \%, 3: 38 \%, 4: 68 \%, 5: 88 \%$ ).
The Detrended correspondence analysis (DCA) was used to summarize the variation in species composition using the species data and interpret this summary with the help of measured and derived environmental variables (EIVs) under CANOCO 5.04 (Šmilauer and Lepš 2014). Canonical Correspondence Analyses (CCA) were run to determine the relationships between species and environmental variables.

Environmental variables significantly affecting the variation in species composition were determined using interactive forward selection with unrestricted permutations as simple (marginal) and conditional effects ( $P$ values adjusted using False discovery rate). The response curves of tree species on the best subset of environmental variables were calculated based on the Generalized Linear Model (GLM). The selection of the best model was performed with the stepwise selection using F-statistic (the lowest deviance value).

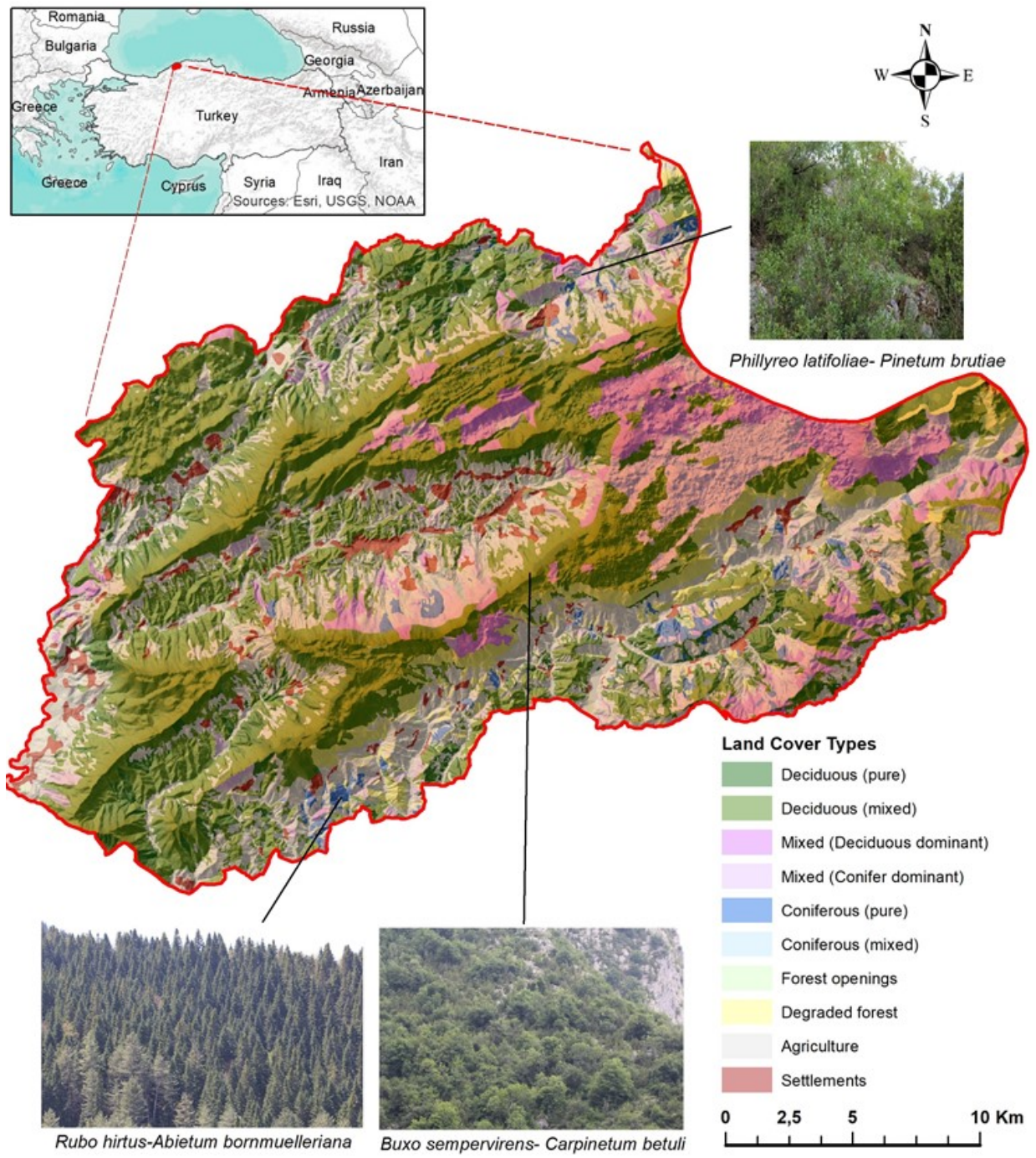

Figure 1. Location of Küre Mountains National Parks (Bartın Section).

Ubicación del Parque Nacional Montañas de Küre (sección Bartin). 


\section{RESULTS}

Forest communities were described under eight associations as Quercetum roburi-Aceretum campestri (Tunçkol 2017), Salicio-Platanetum orientale (Tunçkol 2017), Phillyreo latifoliae-Pinetum brutiae (Schwarz 1936), Buxo sempervirens- Carpinetum betuli (Aksoy 2006), CarpinoQuercetum petraeae (Yurdakulol et al. 2002), Ilici colchicae-Fagetum orientalis (Quezel et al. 1992), Rubo hirtusAbietum bornmuelleriana (Aksoy 2006), Hedero-Castanetum sativae (Yurdakulol et al. 2002) (table 1).

Buxo sempervirens-Carpinetum betuli and Rubo hirtus-Abietum bornmuelleriana occurred at a higher altitudinal zone (over $600 \mathrm{~m}$ ) and others at a lower zone (below $600 \mathrm{~m}$ ). Only Buxo sempervirens- Carpinetum betuli occurred on steep slopes (figure 2).

Among forest associations, the highest species diversity was found in Phillyreo latifoliae-Pinetum brutiae (average 17 species, $2.70 \mathrm{H}^{\prime}$ ), followed by Carpino-Quercetum petraeae (average 18 species, $2.33 \mathrm{H}^{\prime}$ ) and SalicioPlatanetum orientale (average 16 species, $2.33 \mathrm{H}^{\prime}$ ). The lowest diversity was found in Hedero-Castanetum sativae (average eight species, $1.33 \mathrm{H}^{\prime}$ ), which had a dense Rhododendron ponticum L. shrub layer and Quercetum roburiAceretum campestri (average 8 species, $1.72 \mathrm{H}^{\prime}$ ) (figure 3) located on riverbanks. However, Salicio-Platanetum orientale and Buxo sempervirens-Carpinetum betuli had the highest beta diversity among other associations since they harbored unique species composition compared to other forest associations.
The Detrended Correspondence Analysis (DCA) revealed a strong floristic differentiation among relevés except Quercetum roburi-Aceretum campestri and SalicioPlatanetum orientale which had overlapping ordination. Vegetation data had heterogeneous composition with the length of the first axis being $4.83 \mathrm{SD}$ and that of the second axis $4.64 \mathrm{SD}$. The first two axes explained $8.85 \%$ of the variation in species composition. Environmental variables accounted for $21.3 \%$ of the total variation in DCA. While the first axis was associated with altitudinal gradient, the second axis was associated with a moisture gradient. Humidity and nutrient EIVs were associated with Quercetum roburi-Aceretum campestri and Salicio-Platanetum orientale. Phillyreo latifoliae-Pinetum brutiae and Buxo sempervirens-Carpinetum betuli associations were associated with temperature and light EIVs, which also showed correlation with the potential direct incident radiation and heat load. However, soil moisture content did not show correlation with humidity EIVs, although it related to soil $\mathrm{pH}$ and electrical conductivity towards Carpino-Quercetum petraeae (figure 4 ).

Since the response data were compositional and had a gradient of 5.68 SD units long, the linear method was not appropriate. For this reason, CCA, which is a unimodal constrained method, was used. All variables explained $21.9 \%$ of the total variation and most of the factors significantly affected variation in species composition except sand content, heat load and clay content at $P(\operatorname{adj})<0.05$ level ( $P$ values adjusted using False discovery rate). Where conditional effects of the factors considered: soil electri-
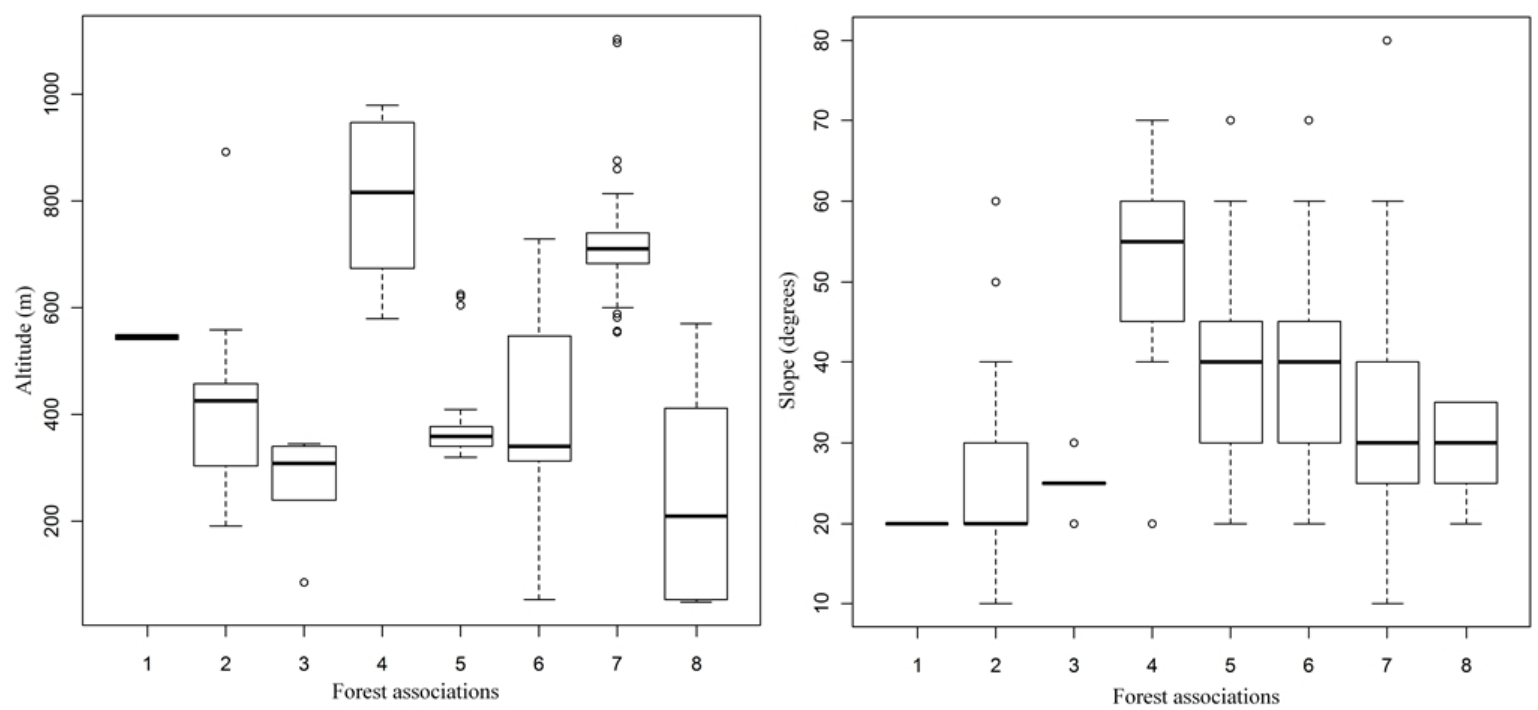

Figure 2. Altitude and slope of forest associations (1: Quercetum roburi-Aceretum campestri, 2: Salicio-Platanetum orientale, 3: Phillyreo latifoliae-Pinetum brutiae, 4: Buxo sempervirens- Carpinetum betuli, 5: Carpino-Quercetum petraeae, 6: Ilici colchicaeFagetum orientalis, 7: Rubo hirtus-Abietum bornmuelleriana, 8: Hedero-Castanetum sativae).

Altitud y pendiente de asociaciones forestales (1: Quercetum roburi-Aceretum campestri, 2: Salicio-Platanetum orientale, 3: Phillyreo latifoliaePinetum brutiae, 4: Buxo sempervirens- Carpinetum betuli, 5: Carpino-Quercetum petraeae, 6: Ilici colchicae-Fagetum orientalis, 7: Rubo hirtusAbietum bornmuelleriana, 8: Hedero-Castanetum sativae). 
Table 1. Percentage synoptic table of forest associations (only species on tree layer were given; 1: Quercetum roburi-Aceretum campestri, 2: Salicio-Platanetum orientale, 3: Phillyreo latifoliae-Pinetum brutiae, 4: Buxo sempervirens- Carpinetum betuli, 5: Carpino-Quercetum petraeae, 6: Ilici colchicae-Fagetum orientalis, 7: Rubo hirtus-Abietum bornmuelleriana, 8: Hedero-Castanetum sativae).

Cuadro sinóptico porcentual de asociaciones forestales (solo se proporcionaron especies en el estrato arbóreo; 1: Quercetum roburi-Aceretum campestri, 2: Salicio-Platanetum orientale, 3: Phillyreo latifoliae-Pinetum brutiae, 4: Buxo sempervirens- Carpinetum betuli, 5: Carpino-Quercetum petraeae, 6: Ilici colchicae-Fagetum orientalis, 7: Rubo hirtus-Abietum bornmuelleriana, 8: Hedero-Castanetum sativae).

\begin{tabular}{|c|c|c|c|c|c|c|c|c|c|}
\hline \multirow{2}{*}{ Variable / Species } & \multirow{2}{*}{ Abbreviation } & \multicolumn{8}{|c|}{ Association $\mathrm{N}^{\mathrm{o}}$} \\
\hline & & 1 & 2 & 3 & 4 & 5 & 6 & 7 & 8 \\
\hline Number of relevés & & 2 & 17 & 5 & 8 & 21 & 31 & 30 & 7 \\
\hline Total number of species & & 12 & 89 & 39 & 74 & 101 & 90 & 94 & 30 \\
\hline Species in tree layer & & & & & & & & & \\
\hline Ulmus glabra Huds. & UlmuGlab & 100 & & & & & 3 & 3 & \\
\hline Quercus robur $\mathrm{L}$. & QuerRobu & 100 & 12 & & & & & & \\
\hline Acer campestre L. & AcerCamp & 100 & & & 13 & & & 13 & \\
\hline Alnus glutinosa (L.) Gaertn. & AlnuGlut & 50 & 18 & & & & 3 & & \\
\hline Salix caprea $\mathrm{L}$. & SaliCapr & 50 & 12 & & & & & & \\
\hline Populus tremula $\mathrm{L}$. & PopuTrem & & 47 & & & 5 & 13 & & \\
\hline Salix alba $\mathrm{L}$. & SaliAlba & & 29 & & & & & & \\
\hline Pinus brutia Ten. & PinuBrut & & & 100 & & & 3 & & 14 \\
\hline Ostrya carpinifolia Scop. & OstrCarp & & & & 50 & & & & 14 \\
\hline Fraxinus angustifolia Vahl & FraxAngu & & & & 38 & & 3 & 3 & 14 \\
\hline Pinus nigra J.F.Arnold & PinuNigr & & & & & 71 & 3 & 3 & 14 \\
\hline Abies bornmuelleriana Mattf. & AbieBorn & & & & & & 3 & 63 & \\
\hline Acer platanoides $\mathrm{L}$. & AcerPlat & & & & & 5 & 10 & 20 & \\
\hline Carpinus orientalis Mill. & CarpOrie & & 29 & & 25 & & & & \\
\hline Castanea sativa Mill. & CastSati & & & & & & 52 & & 100 \\
\hline Fagus orientalis Lipsky & FaguOrie & & & & & 10 & 84 & 90 & 43 \\
\hline Quercus petraea (Matt.) Liebl. & QuerPetr & & & 40 & 25 & 95 & 23 & 13 & 14 \\
\hline Carpinus betulus $\mathrm{L}$. & CarpBetu & & 29 & & 38 & 19 & 81 & 57 & 43 \\
\hline Tilia platyphyllos Scop. & TiliPlat & & & & & & 3 & 3 & 14 \\
\hline Platanus orientalis L. & PlatOrie & & 12 & & & & & & \\
\hline Acer trautvetteri Medw. & AcerTrau & & & & 13 & & & & \\
\hline Malus sylvestris (L.) Mill. & MaluSylv & & 12 & & & & & & \\
\hline Populus alba L. & PopuAlba & & 6 & & & & 6 & & \\
\hline Ulmus minör Mill. & UlmuMino & & 6 & & & & & & \\
\hline Tilia tomentosa Moench & TiliTomn & & & & & & 13 & & \\
\hline Pinus pinaster Aiton & PinuPina & & & & & & 3 & & \\
\hline Fraxinus excelsior $\mathrm{L}$. & FraxExce & & & & & & 6 & 10 & \\
\hline Cerasus avium L. & CeraAviu & & 6 & & & & 6 & 10 & \\
\hline Buxus sempervirens L. & Вихи Semp & & & & & & & 10 & \\
\hline Sorbus aucuparia $\mathrm{L}$. & SorbAucu & & 6 & & & & & 7 & \\
\hline Pinus sylvestris L. & PinuSylv & & 6 & & & & & 3 & \\
\hline Sorbus torminalis (L.) Crantz & SorbTorm & & & & & 5 & 3 & 10 & \\
\hline Corylus avellana $\mathrm{L}$. & CoryAvel & & & & & & & 3 & \\
\hline
\end{tabular}




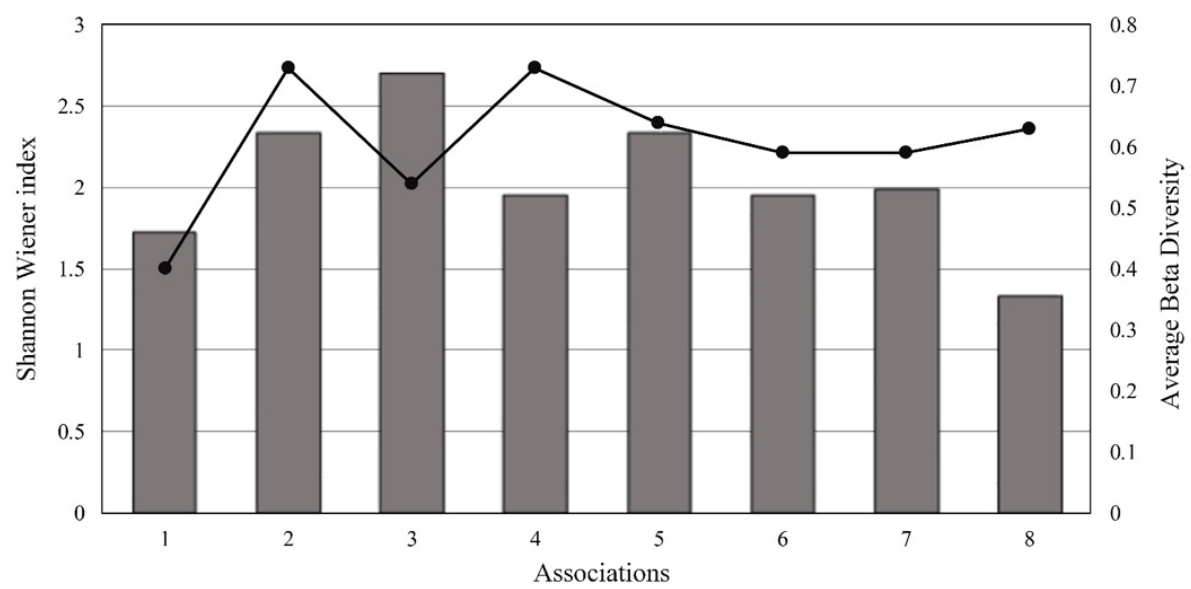

Figure 3. Shannon-Wiener species diversity (column chart) and average beta diversity (black line) of forest communities (1: Quercetum roburi-Aceretum campestri, 2: Salicio-Platanetum orientale, 3: Phillyreo latifoliae-Pinetum brutiae, 4: Buxo sempervirensCarpinetum betuli, 5: Carpino-Quercetum petraeae, 6: Ilici colchicae-Fagetum orientalis, 7: Rubo hirtus-Abietum bornmuelleriana, 8: Hedero-Castanetum sativae).

Diversidad de especies de Shannon-Wiener (gráfico de columnas) y diversidad beta promedio (línea negra) de las comunidades forestales (1: Quercetum roburi-Aceretum campestri, 2: Salicio-Platanetum orientale, 3: Phillyreo latifoliae-Pinetum brutiae, 4: Buxo sempervirens-Carpinetum betuli, 5: Carpino-Quercetum petraeae, 6: Ilici colchicae-Fagetum orientalis, 7: Rubo hirtus-Abietum bornmuelleriana, 8: Hedero-Castanetum sativae).

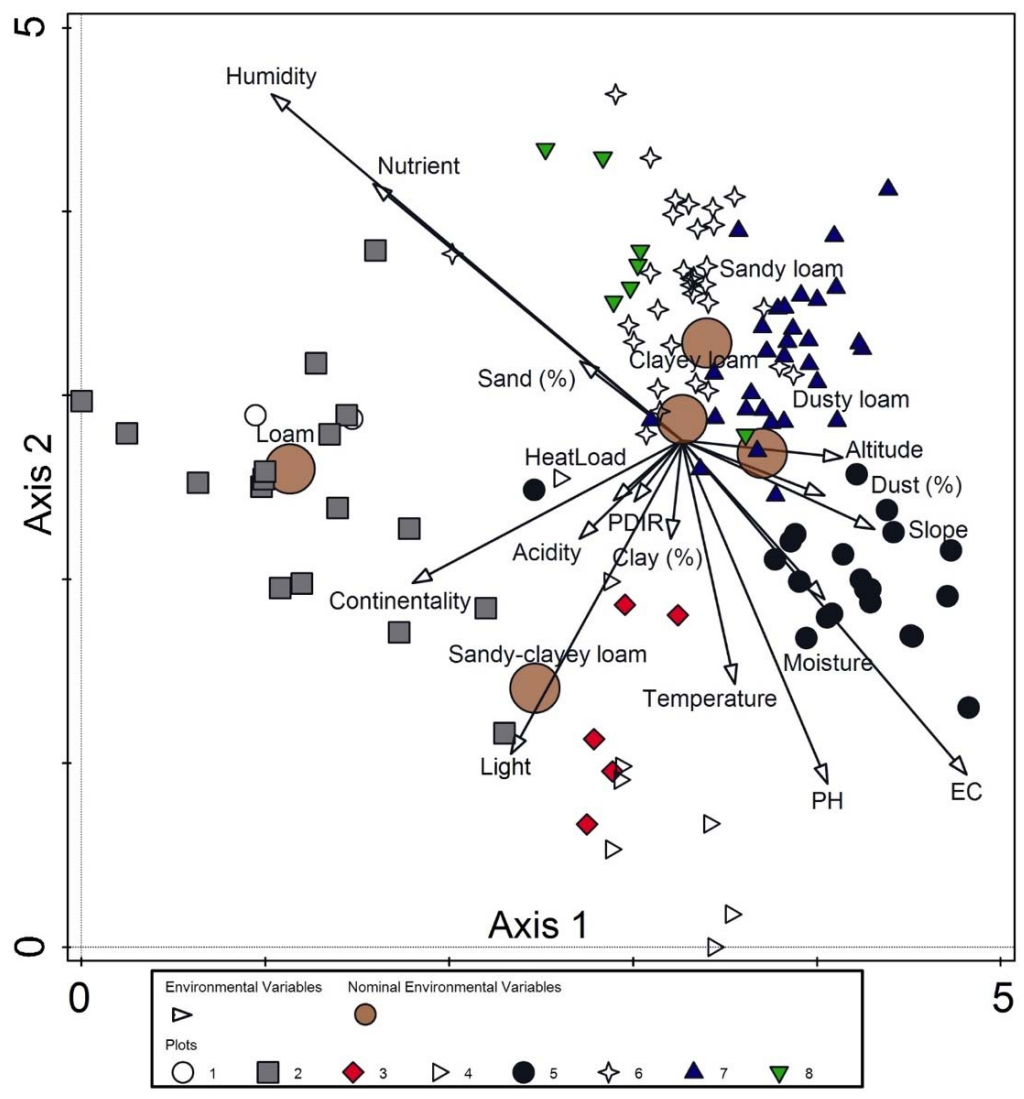

Figure 4. Detrended Correspondence Analysis (DCA) of forest vegetation (1: Quercetum roburi-Aceretum campestri, 2: SalicioPlatanetum orientale, 3: Phillyreo latifoliae-Pinetum brutiae, 4: Buxo sempervirens-Carpinetum betuli, 5: Carpino-Quercetum petraeae, 6: Ilici colchicae-Fagetum orientalis, 7: Rubo hirtus-Abietum bornmuelleriana, 8: Hedero-Castanetum sativae).

Análisis de correspondencia sin tendencia (DCA) de la vegetación forestal (1: Quercetum roburi-Aceretum campestri, 2: Salicio-Platanetum orientale, 3: Phillyreo latifoliae-Pinetum brutiae, 4: Buxo sempervirens-Carpinetum betuli, 5: Carpino-Quercetum petraeae, 6: Ilici colchicae-Fagetum orientalis, 7: Rubo hirtus-Abietum bornmuelleriana, 8: Hedero-Castanetum sativae). 
cal conductivity, altitude, sandy-loam soil type, loam soil type, slope, dust content, sand content and $\mathrm{pH}$ had a significant contribution in species composition at $P($ adj $)<0.05$ (table 2).

Mesic Ilici colchicae-Fagetum orientalis and Rubo hirtus-Abietum bornmuelleriana with their associated species were correlated with altitude, nevertheless soil type

Table 2. Effects of environmental variable on species composition.

Efectos de la variable ambiental sobre la composición de especies.

\begin{tabular}{|c|c|c|c|c|}
\hline \multirow{2}{*}{ Name } & \multicolumn{4}{|c|}{ Simple term effects } \\
\hline & Explains \% & pseudo-F & $P$ & $P(\operatorname{adj})$ \\
\hline Electrical conductivity & 3.5 & 4.3 & 0.002 & 0.03 \\
\hline Altitude (m) & 3.1 & 3.8 & 0.002 & 0.03 \\
\hline Sandy-clay loam & 2.9 & 3.5 & 0.002 & 0.03 \\
\hline $\mathrm{pH}$ & 2.8 & 3.5 & 0.002 & 0.03 \\
\hline Dusty loam & 2.8 & 3.4 & 0.002 & 0.03 \\
\hline Loam & 2.4 & 2.9 & 0.002 & 0.03 \\
\hline Moisture\% & 2.3 & 2.8 & 0.002 & 0.03 \\
\hline Slope (degrees) & 2.1 & 2.5 & 0.002 & 0.03 \\
\hline Dust $\%$ & 1.6 & 1.9 & 0.002 & 0.03 \\
\hline Sandy loam & 1.5 & 1.9 & 0.002 & 0.03 \\
\hline Clay loam & 1.4 & 1.7 & 0.002 & 0.03 \\
\hline $\begin{array}{l}\text { Potential direct } \\
\text { incident radiation }\end{array}$ & 1.2 & 1.5 & 0.010 & 0.04 \\
\hline Sand $\%$ & 1.2 & 1.4 & 0.020 & 0.06 \\
\hline Heat load & 1.1 & 1.3 & 0.096 & 0.19 \\
\hline Clay\% & 0.8 & 1.0 & 0.510 & 0.51 \\
\hline \multicolumn{5}{|c|}{ Conditional term effects } \\
\hline Electrical conductivity & 3.5 & 4.3 & 0.002 & 0.005 \\
\hline Altitude (m) & 3.3 & 4.2 & 0.002 & 0.005 \\
\hline Sandy-clay loam & 2.6 & 3.4 & 0.002 & 0.005 \\
\hline Loam & 2.3 & 3.0 & 0.002 & 0.005 \\
\hline Dusty loam & 1.6 & 2.1 & 0.002 & 0.005 \\
\hline Slope (degrees) & 1.3 & 1.7 & 0.026 & 0.043 \\
\hline Dust $\%$ & 1.5 & 2.0 & 0.002 & 0.005 \\
\hline $\mathrm{pH}$ & 1.2 & 1.7 & 0.022 & 0.041 \\
\hline Sand $\%$ & 1.3 & 1.8 & 0.004 & 0.008 \\
\hline Clay loam & 1.0 & 1.3 & 0.056 & 0.084 \\
\hline Sandy loam & 1.0 & 1.3 & - & - \\
\hline $\begin{array}{l}\text { Potential direct } \\
\text { incident radiation }\end{array}$ & 0.9 & 1.2 & 0.102 & 0.139 \\
\hline Moisture\% & 0.7 & 0.9 & 0.532 & 0.665 \\
\hline Heat load & 0.7 & 0.9 & 0.630 & 0.726 \\
\hline Clay $\%$ & 0.2 & 0.3 & 0.888 & 0.951 \\
\hline
\end{tabular}

did not make a significant contribution. On the other hand, soil characteristics made a significant effect on the variation of species composition at lower altitudes. CarpinoQuercetum petraeae was found on soil with high dust content with a high $\mathrm{pH}$ and also electrical conductivity values. On the other hand, Quercetum roburi-Aceretum campestri and Salicio-Platanetum orientale were related to soil with loam (figure 5).

Response models of trees over altitudinal gradient showed increasing linear response for Acer platanoides, Fraxinus excelsior, Fraxinus angustifolia and Ostrya carpinifolia. Other trees showed a quadratic distribution over altitude (table S1 in Supplementary material). While the optimum distribution of Abies nordmanniana subsp. bornmuelleriana and Fagus orientalis was found between 800$900 \mathrm{~m}$, it was found under $600 \mathrm{~m}$ for Pinus brutia, Pinus nigra, Quercus petraea, Tilia tomentosa, Castanea sativa and Salix alba in the study area (figure 6). While Buxus sempervirens and Ostrya carpinifolia showed an increasing linear distribution, Carpinus betulus had a decreasing response on the slope. Other trees had quadratic distribution on the slope (table S1 in Supplementary material). Castanea sativa, Fagus orientalis, Fraxinus excelsior, Pinus nigra, Quercus petraea and Ostrya carpinifolia had their optimum on steep slopes (over 30 degrees) and Abies nordmanniana subsp. bornmuelleriana, Pinus brutia, Alnus glutinosa, Salix caprea, Quercus robur and Platanus orientalis had optimum on moderately steep slopes (under 30 degrees) (figure 6).

Species responses to soil content varied for most species. Most species showed quadratic distribution on soil parameters. However, Carpinus betulus had a clear decreasing linear response on dust content and Quercus robur an increasing linear response on sand content (table S2 in Supplementary material). While Pinus nigra and Castanea sativa showed a good development on the soil with a higher dust content (over 50 \%), Fagus orientalis, Abies nordmanniana subsp. bornmuelleriana, Carpinus betulus and Acer campestre did it on soil with higher sand content (over $70 \%$ ). On the other hand, species such as Carpinus orientalis, Salix alba and Populus tremula had optimum soil dust content around 30-45\%. In terms of soil $\mathrm{pH}$ and electrical conductivity, some species such as Castanea sativa, Abies nordmanniana subsp. bornmuelleriana, Fagus orientalis, Populus tremula, Quercus robur showed similar responses. Pinus nigra and Quercus petraea, which were found on alkaline soils presenting high electrical conductivity. Pinus brutia, Pinus nigra and Quercus petraea had an increasing response on moderately alkaline soils $(\mathrm{pH}$ 7-8). Castanea sativa, Tilia tomentosa, Pinus pinaster and Fagus orientalis had their optimum on moderately acidic soils (pH 5.6-6) and Populus tremula, Ulmus minor and Alnus glutinosa on slightly acidic soils (pH 6.1-6.5). On the other hand, Salix caprea, Quercus robur, Abies nordmanniana subsp. bornmuelleriana and Carpinus orientalis were found on neutral soils (figure 7). 


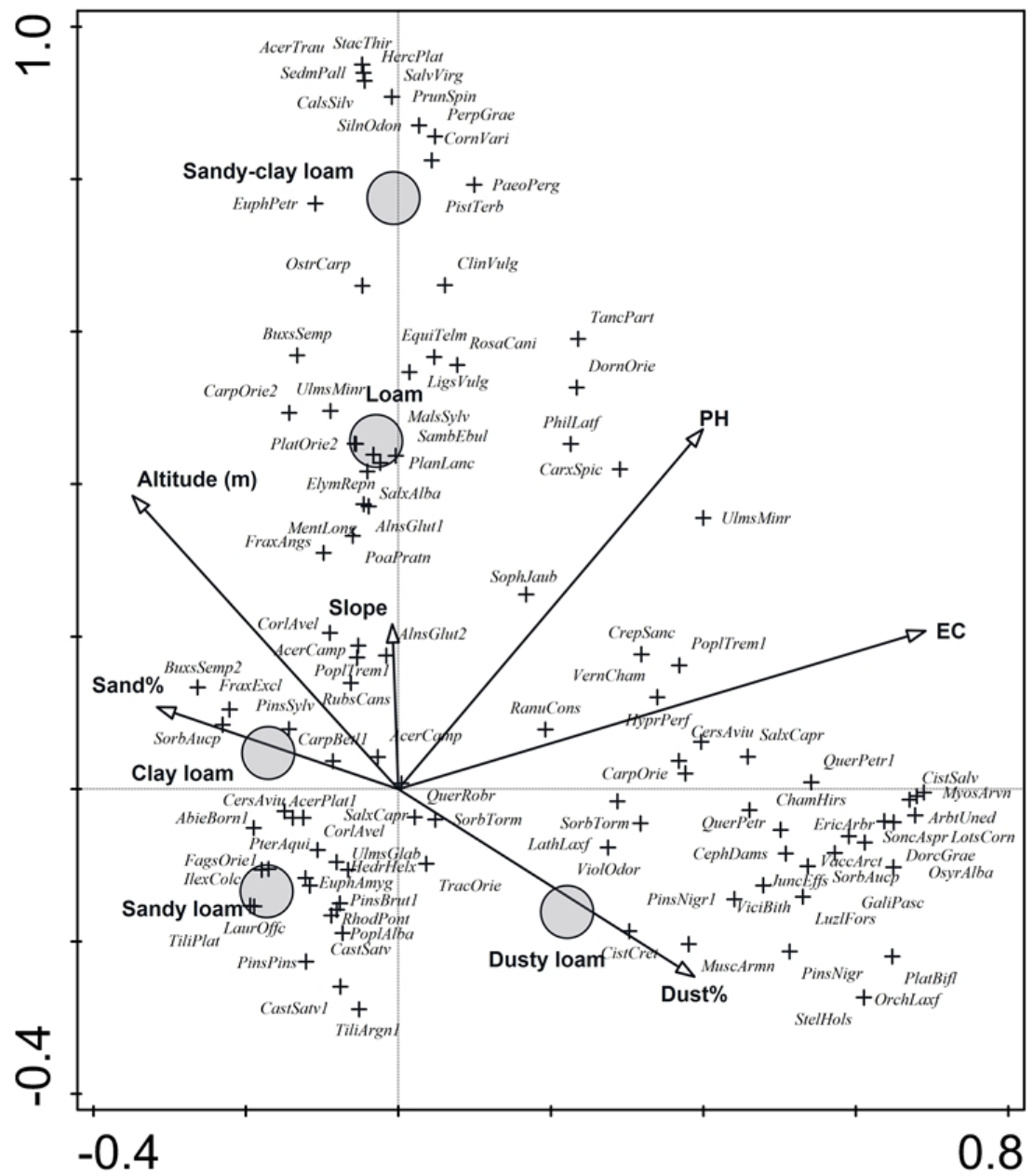

Figure 5. Canonical Correspondence Analysis (CCA) graph of forest vegetation (see table 1 for abbreviations of the species, number at the end of the abbreviations 1: tree layer, 2: second tree layer, others are in shrub or herb layers).

Análisis de Correspondencia Canónica (CCA) de la vegetación forestal (ver cuadro 1 para las abreviaturas de las especies, número al final de las abreviaturas $=1$ : capa de árboles, 2 : segunda capa de árboles, otras están en capas de arbustos o hierbas).
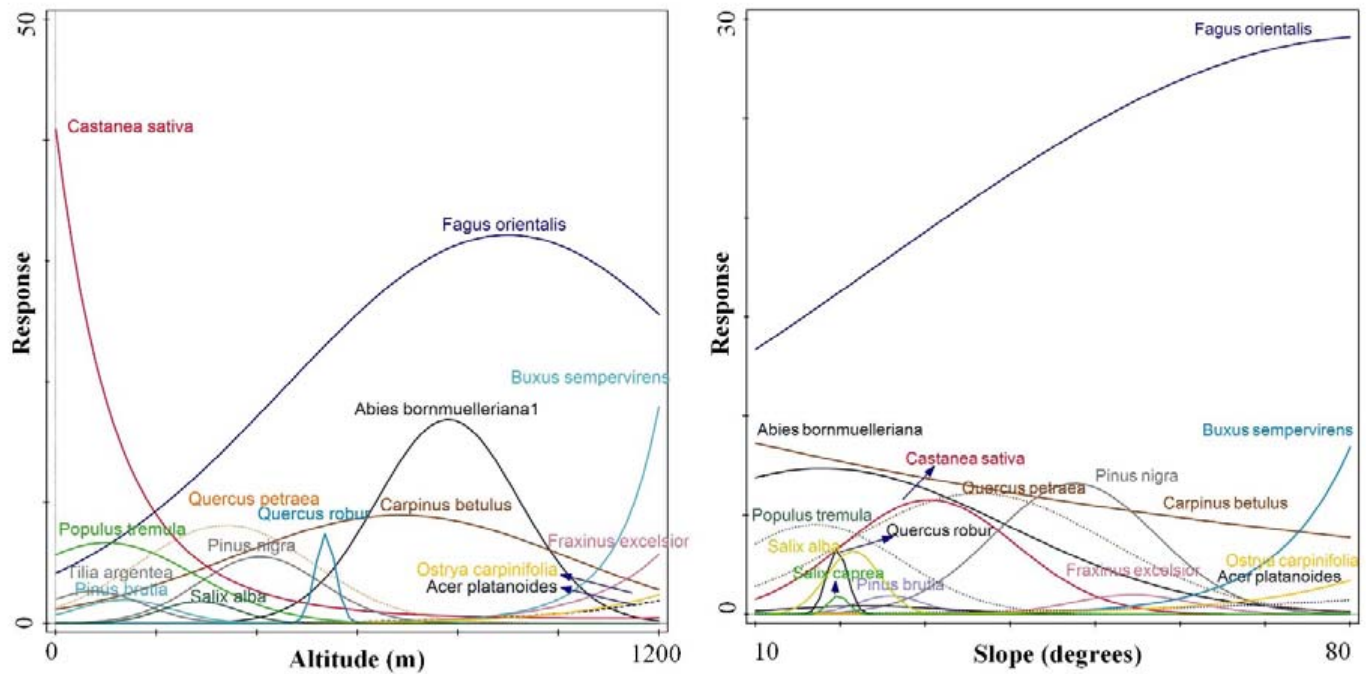

Figure 6. Species response curves against topographical variables.

Curvas de respuesta de las especies frente a variables topográficas. 

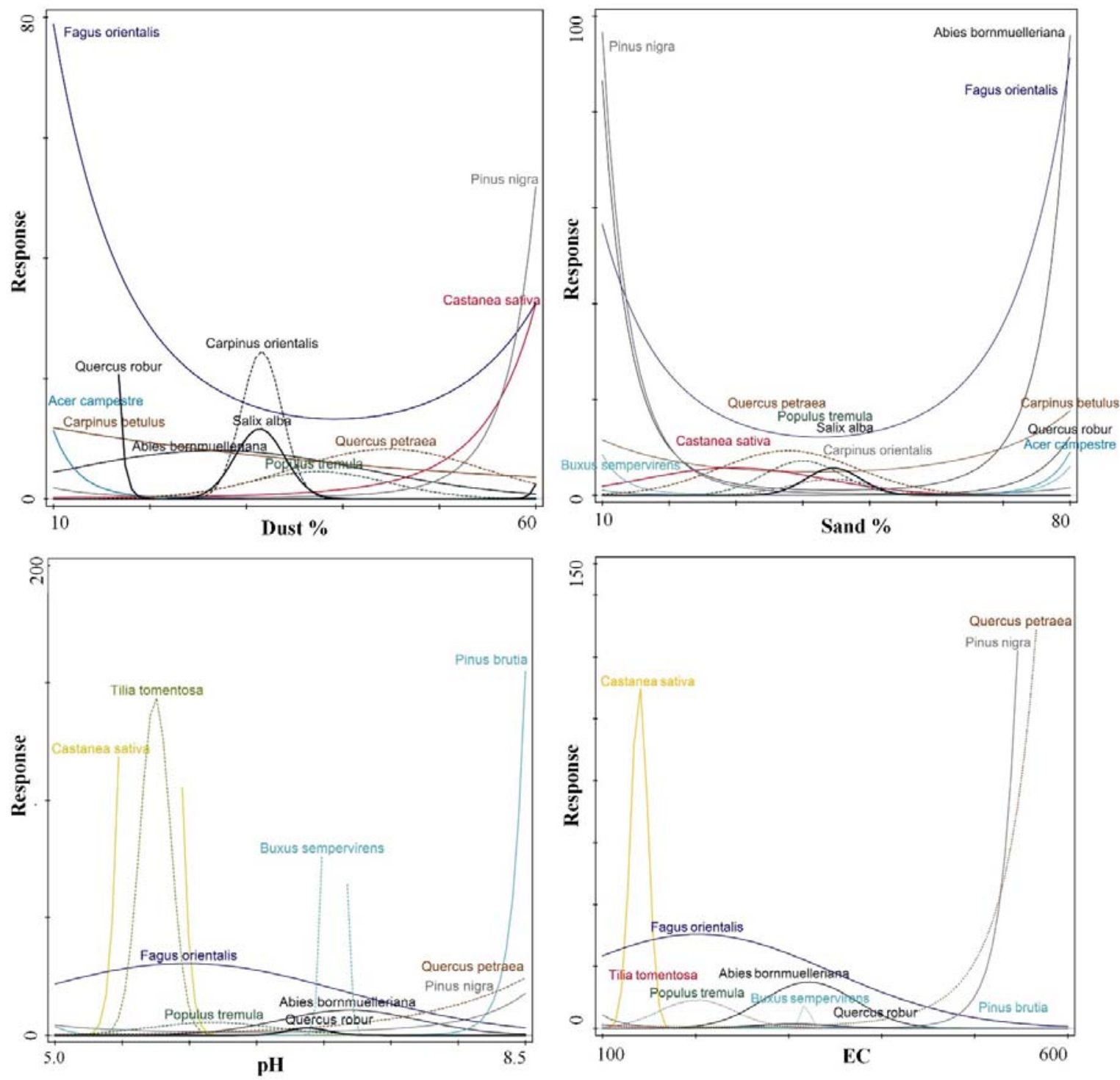

Figure 7. Species response curves against soil parameters (EC: electrical conductivity).

Curvas de respuesta de especies frente a parámetros del suelo.

\section{DISCUSSION}

According to Bartels and Chen (2010), understory plants are limited by light availability under closed and stratified canopies in young/mature stages of stand development. However, resource quantity and heterogeneity may be key factors in structuring understory species diversity in stands that experience intermediate disturbances. In the study area, the highest species diversity is found in Phillyreo latifoliae-Pinetum brutiae, which has a low canopy cover and single-layered stand structure. In addition, Carpino-Quercetum petraeae and Salicio-Platanetum orientale had also higher species diversity compared to other deciduous forest communities owing to leaf structure enabling transmission of more light in the understory and low canopy cover. The species diversity of the abovementioned communities is also confirmed by the study of Messier et al. (1998) who reported shade-intolerant species (deciduous or coniferous) transmit more light than do shade tolerant tree species. This situation is also revealed with the higher light EIVs of these units (figure 4). Light EIVs, which has a high positive correlation with the potential direct incident radiation and heat load, related to Phillyreo latifoliae-Pinetum brutiae and Salicio-Platanetum orientale. Even though intermediate scale disturbance may increase light conditions in the understory, severe disturbances contribute to the spread of Rhododendron spp. in the temperate forest systems, which decrease species diversity (Royo and Carson 2006) as shown with HederoCastanetum sativae association, which has a dense Rhodo- 
dendron ponticum layer. However, forests with azonal character and extreme site conditions (steep slopes) have higher beta diversity such as Salicio-Platanetum orientale and Buxo sempervirens-Carpinetum betuli. Thus, the first hypothesis was approved since different forest types (coniferous, deciduous-mixed and riparian forests) occurring on heterogeneous ecological conditions exhibit high alpha and/or beta diversity in the region. This was shown both with the alpha and beta diversity of the communities and the gradient length in the DCA ordination indicating a large beta diversity.

Assessment of many species occurring together allows a more reliable estimation of site conditions than does assessment of a single species, as the overlap of ecological tolerances of many species is smaller than the ecological amplitude of a single species. For this reason, mean indicator values of species in a sample plot or community may provide more reliable information (Çoban 2016). For instance, Quercetum roburi-Aceretum campestri and SalicioPlatanetum orientale, which occur on riversides, differed from other communities with nutrient and humidity EIVs. The high nutrient cycling capacity of riparian forests compared to upland ecosystems is probably the consequence of their open structure to fluvial sources via flood deposits and to lateral fluxes of nutrients from the drainage basin (Pinay et al. 1995).

Changes in plant community composition are usually well correlated with changes in soil conditions such as $\mathrm{pH}$, organic matter, weathering processes and nutrient availability (Wardle et al. 2004). On the other hand, climate is primarily effective on the variation of forest community composition over altitudinal gradient. Soil characteristics also change depending on the climate. The effects of elevation on growth are due to multiple interacting factors, including temperature, soil depth, precipitation and exposure. In addition to altitude, topographical variables such as slope and aspect influence the forest composition. While aspect can affect species composition and soil properties --including soil moisture, $\mathrm{pH}$, organic matter content and nutrient cycling-- slope gradient can affect soil thickness, water and nutrient retention, among other factors (Gilliam et al. 2014, Robin-Abbott and Pardo 2017). At this point, the effects of site condition parameters may vary in combination with other variables. For instance, Rubo hirtus-Abietum bornmuelleriana, which prefer higher altitudes, cannot compete with Buxo sempervirens- Carpinetum betuli on steep slopes (figures 2 and 4). However, the effect of the potential direct incident radiation and heat load calculated from slope gradient and aspect is not significant in combination of variables. These indexes may give better results for wide areas (e.g. at continental scale). Nonetheless, the slope gradient made alone a significant contribution, especially for Buxus sempervirens, Pinus nigra, Ostrya carpinifolia since it affected soil thickness. Therefore, the second hypothesis is true only for measured topographical variables though not for potential direct incident radiation and heat load which may give better results for larger areas.

Soil types of the forests are important for water and nutrient availability. In general, soils with sufficient water, nutrients and adequate drainage (e.g., sandy loams to clay loams) can be accepted as favorable site conditions for most trees. Clay soils are often fertile, although heavy and poorly drained. Sandy soils are lighter, though they lack water and nutrients (Robin-Abbott and Pardo 2017). For this reason, sandy loam soil type provided favorable conditions for Abies nordmanniana subsp. bornmuelleriana and Fagus orientalis. On the other hand, more tolerant species such as Pinus nigra and Quercus petraea are associated with dusty soils (figures 4, 5 and 7). MacDonald (2003) defined this phenomenon as "Competitive Exclusion Principle”, which means fully competitive species cannot cooccur. Therefore, small scale variations in site conditions (i.e. altitudinal zones, steep slopes, soil type etc.) within an environment enable an array of species with similar site requirements as shown in figures 6 and 7, where species showed varied responses to environmental parameters.

In conclusion, although only $21.9 \%$ of the total variation could be explained with the measured environmental variables, an ecological differentiation among forest communities could be made using topographical (altitude and slope) and some of the soil variables (soil type, EC, $\mathrm{pH}$, dust and sand content) as also shown with different response curves of main tree species. In general, distribution of Buxo sempervirens-Carpinetum betuli and Rubo hirtus-Abietum bornmuelleriana within higher altitudinal zone (over $600 \mathrm{~m}$ ) differed with the steepness of the site. On the other hand, soil characteristics affected distribution of other forest communities at lower altitudes where Phillyreo latifoliae-Pinetum brutiae occurred on alkaline soils, Hedero-Castanetum sativae on soil with high dust content, Carpino-Quercetum petraeae on high soil electrical conductivity and Ilici colchicae-Fagetum orientalis with low dust content though high sand content providing weathering processes.

The main differences were also reflected using EIVs for humidity, nutrient, light and temperature EIVs using limited numbers of species having indicator values. However, EIVs did not show a good correlation with associated soil parameters such as soil moisture-humidity EIVs and soil pH-acidity EIVs. According to Londo et al. (2006), nutrients can become either toxic or unavailable at extremes $\mathrm{pH}$, while soils with a $\mathrm{pH}$ of $6.0-7.0$ often have the highest concentration of available nutrients (Williston and Lafayette 1978). The extreme $\mathrm{pH}$ and electrical conductivity values are found for Pinus brutia, Pinus nigra and Quercus petraea, which negatively correlated with nutrient and humidity EIVs. Therefore, only nutrient and humidity EIVs seem to be associated with soil $\mathrm{pH}$ and electrical conductivity values in the study area. However, calibration and assignment EIVs for the flora of Turkey may give better results. 


\section{ACKNOWLEDGEMENTS}

This study was supported by TÜBİTAK, Project number: 1140660. Authors would like to thank Prof. Dr. Süleyman Akbulut and Prof. Dr. Doğanay Tolunay for their valuable comments which helped to improve the manuscript.

\section{REFERENCES}

Aksoy N. 2006. Vegetation of Düzce-Elmacik Mountain. Doctoral Thesis. İstanbul, Turkey. İstanbul University. $415 \mathrm{p}$.

Aksoy N, S Çoban. 2017. Forest communities and ecological differentiation of the Mt. Elmacik (Düzce, Turkey). Journal of Environmental Biology 38(5): 923-929. DOI: $\underline{10.22438 /}$ $\mathrm{jeb} / 38 / 5(\mathrm{SI}) / \mathrm{GM}-08$

Aksoy N, H Zengin, S Çoban, B Tunçkol. 2017. Küre Dağları Milli Parkı'nın Bitki Toplumları ve Florası (Bartın Bölümü). Düzce, Turkey. TÜBİTAK TOVAG Proje Sonuç Raporu. 364 p.

Bartels SF, HY Chen. 2010. Is understory plant species diversity driven by resource quantity or resource heterogeneity? Ecology 91: 1931-1938. DOI: 10.1890/09-1376.1

Blanquet BJ. 1932. Plant Sociology: The Study of Plant Communities. New York, USA. McGraw-Hill Book. 439 p.

Blumer A. 2010. Sürdürülebilir Turizm Gelişim Stratejisi (KDMP). Istambul, Turkey. WWF.153 p.

Çoban S. 2016. Ecological indicator values of forest communities in Çitdere Region (Yenice-Karabük). Journal of the Faculty of Forestry Istanbul University 66(1): 278-287. DOI: $\underline{10.17099 / \text { jffiu. } 60821}$

Çoban S, G Özalp. 2012. The vegetation analysis of mixed Uludag Fir (Abies bornmulleriana Mattf.) forests in Bolu Ayikaya Region/Turkey. Bartın Orman Fakültesi Dergisi 14: 62-73.

Dwire KA, JB Kauffman, EJ Brookshire, JE Baham. 2004. Plant biomass and species composition along an environmental gradient in montane riparian meadows. Oecologia 139(2): 309-317.

Ekici B. 2012. Mapping of the biotopes in the Kurucasile (Bartin) coastline and its surrounding areas. Bartın, Turkey. Doctoral Thesis, Bartın Üniversitesi. 376 p.

Ellenberg H. 1979. Zeigerwerte der Gefässpflanzen Mitteleuropas. In Indicator values of Central European vascular plants. Scripta Geobotanica 9: 1-121.

Ellenberg H, HE Weber, R Düll, V Wirth, W Werner, D Paulissen. 1992. Zeigerwerte von Pflanzen. In Mitteleuropa. 2nd ed. Scripta Geobotanica 18: 1-248.

Gilliam FS, R Hédl, M Chudomelová, RL Mcculley, JA Nelson. 2014. Variation in vegetation and microbial linkages with slope aspect in a montane temperate hardwood forest. Ecosphere 5: 1-17. DOI: 10.1890/ES13-00379.1

Göncüoğlu CM, Ö Bozkaya, A Türkmenoğlu, Ö Ünlüce, C Okuyucu. 2015. Geochemical Characteristics and Origin of Late Devonian K-Bentonites from Bartın-Zonguldak-Karabük area. In Proceedings of "16. Nat. Clay Symposium" 02-05 Sep. 2015. Çanakkale, Turkey. p. 26-27.

Jean-Claude G, K Eva. 2003. Comparison of indicator values of forest understory plant species in Western Carpathians (Slovakia) and Vosges Mountains (France). Forest Ecology and Management 182: 1-11. DOI: 10.1016/S0378$\underline{1127(03) 00068-9}$
Kent M, P Coker. 1992. Vegetation description and analysis: a practical approach. Chichester, England. John Wiley. 384 p.

Londo AJ, JD Kushla, RC Carter. 2006. Soil pH and tree species suitability in the south. Athens, Greece. Southern Regional Extension Forestry. GA, SREF-FM-002. p. 1-4.

Macdonald GM. 2003. Biogeography: Introduction to space, time, and life. London, UK. John Wiley. 528 p.

McCune B, D Keon. 2002. Equations for potential annual direct incident radiation and heat load. Journal of Vegetation Science 13(4): 603-606. DOI: $10.1111 / j .1654-1103.2002$. tb02087.x

Messier C, S Parent, Y Bergeron. 1998. Effects of overstory and understory vegetation on the understory light environment in mixed boreal forests. Journal of Vegetation Science 9: 511-520. DOI: $\underline{10.2307 / 3237266}$

Mueller D, HD Ellenberg. 1974. Aims and methods of vegetation ecology. New York, USA. John Willey. 547 p

Pignatti S, P Bianco, G Fanelli, R Guarino, J Petersen, P Tescarollo. 2001. Reliability and effectiveness of Ellenberg's indices in checking flora and vegetation changes induced by climatic variations. In Körner C, GR Walther, CA Burga, PJ Edwards eds. Fingerprints of climate change, adapted behaviour and shifting species ranges. New York, USA. Kluwer Academic/Plenum Publishers. p. 281-300.

Pinay G, C Ruffinoni, A Fabre. 1995. Nitrogen cycling in two riparian forest soils under different geomorphic conditions. Biogeochemistry 30(1): 9-29. https://link.springer.com/article/10.1007/BF02181038

Quézel P, M Barbéro, Y Akman. 1992. Typification de Syntaxa Décrits en Region Méditerranéenne Orientale. Ecologia Mediterranea 18: 61-87. DOI: 10.3406/ECMED.1992.1708

Robin-Abbott MJ, LH Pardo. 2017. How climatic conditions, site, and soil characteristics affect tree growth and critical loads of nitrogen for northeastern tree species. Gen. Tech. Rep. NRS-172. Newtown Square, USA. US Department of Agriculture, Forest Service, Northern Research Station. 143 p. DOI: $10.2737 /$ NRS-GTR-172.

Royo AA, WP Carson. 2006. On the formation of dense understory layers in forests worldwide: consequences and implications for forest dynamics, biodiversity, and succession. Canadian Journal of Forest Research 36(6): 1345-1362. DOI: $10.1139 / \mathrm{x} 06-025$

Schaffers AP, KV Sýkora. 2000. Reliability of Ellenberg indicator values for moisture, nitrogen and soil reaction: a comparison with field measurements. Journal of Vegetation Science 11(2): 225-244. DOI: $\underline{10.2307 / 3236802}$

Şengönül K, Ö Kara, Ş Palta, H Şensoy. 2009. Bartın Uluyayla Yöresindeki Mera ve Vejetasyonun Bazı Kantitatif Öze1liklerinin Saptanması ve Ekolojik Yapılarının Belirlenmesi. Bartın Orman Fakültesi Dergisi 11(16): 81-94. https:// pdfs.semanticscholar.org/b855/d609e972affac5221 ea8baa6630c5dda9e33.pdf

Šmilauer P, J Lepš. 2014. Multivariate analysis of ecological data using CANOCO 5. Cambridge, UK. Cambridge University Press. 376 p. DOI: $10.1017 / \mathrm{CBO} 9781139627061$

Schwarz O. 1936. Die Vegetations Verhaltnisse West Anatoliens. Englers Botanische Jahrbücher für Systematic 67: 297-436.

Tichý L, J Holt. 2006. Juice program for management, analysis and classification of ecological data. Brno, Czech Republic. Masaryk University. 103 p.

Tunçkol B. 2017. Plant communities and flora of Küre Mountains National Park (Bartın Section). Düzce, Turkey. Docto- 
rate thesis. Düzce University. $355 \mathrm{p}$.

Uz B, T Öztaş, F Esenli, Ş Özdamar. 2001. Geological and Petrographical Characteristic of Düzköy-Düzağaç (Ulus-Bartın) Travertine Occurances and Their Utilization as Marble. In Proceedings of Türkiye III. Mermer Sempozyumu Bildiriler Kitab1, 3-5 May. Afyon, Turkey. p. 33-40.

Wamelink G, PW Goedhart, HF Van Dobben, F Berendse. 2005. Plant species as predictors of soil $\mathrm{pH}$ : Replacing expert judgement with measurements. Journal of Vegetation Science 16: 461-470. DOI: 10.1111/j.1654-1103.2005.tb02386.x

Wardle DA, LR Walker, RD Bardgett. 2004. Ecosystem pro- perties and forest decline in contrasting long-term chronosequences. Science 305: 509-513. DOI: $\underline{10.1126 / \text { scien- }}$ $\underline{\text { ce. } 1098778}$

Williston HL, R LaFayette. 1978. Species suitability and $\mathrm{pH}$ of soils in southern forests. Forestry Management Bulletin. Atlanta, USA. U.S. Department of Agriculture, Forest Service, Southeastern Area, State and Private Forestry. 5 p.

Yurdakulol E, M Demirörs, A Y1ldiz. 2002. A phytosociological study of the vegetation of the Devrekani-Innebolu-Abana area (Kastamonu, Turkey). Israel Journal of Plant Sciences 50(4): 293-311. DOI: 10.1560/NQUF-CB48-BYA7-NGVD.

Recibido: 08/06/20

Aceptado: 17/07/20 


\section{SUPPLEMENTARY MATERIAL}

Table S1. Results of species response curves of trees for topographical parameters.

Resultados de las curvas de respuesta de especies de árboles para parámetros topográficos.

\begin{tabular}{|c|c|c|c|c|c|c|}
\hline Predictors & Altitude (m) & & & & & \\
\hline Distribution & Poisson & & & & & \\
\hline Link function & $\log$ & & & & & \\
\hline \multicolumn{7}{|c|}{ GLM fitted for 31 response variables: } \\
\hline Response & Type & $\mathrm{R}^{2}[\%]$ & $\mathrm{F}$ & $P$ & Optimum & Tolerance \\
\hline Abies bornmuelleriana & quadratic & 36.3 & 468.4 & $<0.00001$ & NA & NA \\
\hline Acer campestre & quadratic & 15.1 & 11.7 & 0.00002 & NA & NA \\
\hline Acer platanoides & linear & 19.3 & 18.8 & 0.00003 & NA & NA \\
\hline Carpinus betulus & quadratic & 3.8 & 44.7 & $<0.00001$ & NA & NA \\
\hline Castanea sativa & quadratic & 26.0 & 252.9 & $<0.00001$ & NA & NA \\
\hline Fagus orientalis & quadratic & 7.5 & 189.0 & $<0.00001$ & NA & NA \\
\hline Fraxinus angustifolia & linear & 14.3 & 11.2 & 0.00107 & NA & NA \\
\hline Fraxinus excelsior & linear & 37.6 & 48.7 & $<0.00001$ & NA & NA \\
\hline Pinus brutia & quadratic & 38.6 & 34.1 & $<0.00001$ & NA & NA \\
\hline Pinus nigra & quadratic & 16.8 & 121.1 & $<0.00001$ & NA & NA \\
\hline Pinus pinaster & quadratic & 69.1 & 9.9 & 0.00072 & 305.04 & 4.47 \\
\hline Pinus sylvestris & quadratic & 42.1 & 5.2 & 0.00676 & 506.77 & 38.51 \\
\hline Populus alba & quadratic & 25.3 & 18.3 & $<0.00001$ & 242.13 & 66.64 \\
\hline Populus tremula & quadratic & 22.5 & 138.3 & $<0.00001$ & NA & NA \\
\hline Quercus petraea & quadratic & 15.6 & 161.6 & $<0.00001$ & NA & NA \\
\hline Tilia tomentosa & quadratic & 48.1 & 43.4 & $<0.00001$ & NA & NA \\
\hline Tilia platyphyllos & quadratic & 34.4 & 6.4 & 0.00226 & 597.78 & 51.34 \\
\hline Acer trautvetteri & quadratic & 96.7 & 9.3 & 0.09732 & 1035.88 & 7.48 \\
\hline Alnus glutinosa & quadratic & 9.7 & 11.6 & 0.00003 & NA & NA \\
\hline Buxus sempervirens & quadratic & 34.9 & 38.9 & $<0.00001$ & NA & NA \\
\hline Carpinus orientalis & quadratic & 5.8 & 14.5 & $<0.00001$ & NA & NA \\
\hline Corylus avellana & quadratic & 73.8 & 3.5 & 0.05191 & 737.27 & 5.08 \\
\hline Malus sylvestris & quadratic & 88.2 & 7.2 & 0.01338 & 460.75 & 6.46 \\
\hline Ostrya carpinifolia & linear & 25.4 & 22.7 & $<0.00001$ & NA & NA \\
\hline Platanus orientalis & quadratic & 84.2 & 20.7 & 0.0038 & 442.49 & 4.61 \\
\hline Quercus robur & quadratic & 57.4 & 123.6 & $<0.00001$ & 536.15 & 20.03 \\
\hline Salix alba & quadratic & 23.1 & 57.4 & $<0.00001$ & NA & NA \\
\hline Salix caprea & quadratic & 17.6 & 11.8 & 0.00002 & NA & NA \\
\hline Sorbus aucuparia & quadratic & 37.0 & 5.6 & 0.00503 & 814.38 & 75 \\
\hline Ulmus glabra & quadratic & 41.0 & 11.2 & 0.00004 & 573.65 & 50.19 \\
\hline Ulmus minor & quadratic & 97.9 & 14.1 & 0.00239 & 562.61 & 2.53 \\
\hline
\end{tabular}

Continue 
Table S1 Continued

\begin{tabular}{|c|c|c|c|c|c|c|}
\hline Predictors & \multicolumn{6}{|c|}{ Slope (degrees) } \\
\hline Distribution & \multicolumn{6}{|l|}{ Poisson } \\
\hline Link function & \multicolumn{6}{|l|}{$\log$} \\
\hline \multicolumn{7}{|c|}{ GLM fitted for 27 response variables: } \\
\hline Response & Type & $\mathrm{R} 2[\%]$ & $\mathrm{F}$ & $P$ & Optimum & Tolerance \\
\hline Abies bornmuelleriana & quadratic & 4.6 & 59.9 & $<0.00001$ & 17.93 & 21.79 \\
\hline Acer campestre & linear & 7.3 & 11.3 & 0.00106 & NA & NA \\
\hline Acer platanoides & linear & 6.7 & 6.5 & 0.01178 & NA & NA \\
\hline Carpinus betulus & linear & 0.8 & 19.2 & 0.00003 & NA & NA \\
\hline Castanea sativa & quadratic & 8.7 & 85.2 & $<0.00001$ & 30.49 & 10.21 \\
\hline Fagus orientalis & quadratic & 1.6 & 40.7 & $<0.00001$ & 83.31 & 58.68 \\
\hline Fraxinus excelsior & quadratic & 35.0 & 22.7 & $<0.00001$ & 54.35 & 7.06 \\
\hline Pinus brutia & quadratic & 27.1 & 23.9 & $<0.00001$ & 25.85 & 3.87 \\
\hline Pinus nigra & quadratic & 18.9 & 136.8 & $<0.00001$ & 47.61 & 9.61 \\
\hline Pinus pinaster & quadratic & 33.7 & 4.9 & 0.0127 & 30.02 & 1.11 \\
\hline Populus alba & quadratic & 8.2 & 6.0 & 0.0034 & 37.6 & 8.16 \\
\hline Populus tremula & quadratic & 16.7 & 103.1 & $<0.00001$ & 16.98 & 10.09 \\
\hline Quercus petraea & quadratic & 4.2 & 43.1 & $<0.00001$ & 36.18 & 15.34 \\
\hline Tilia tomentosa & quadratic & 9.7 & 8.8 & 0.00028 & 22.92 & 9.55 \\
\hline Tilia platyphyllos & quadratic & 23.2 & 4.3 & 0.01515 & 35.74 & 3.23 \\
\hline Acer trautvetteri & quadratic & 77.1 & 7.4 & 0.0126 & 70.28 & 2.25 \\
\hline Alnus glutinosa & quadratic & 25.6 & 30.7 & $<0.00001$ & 18.97 & 6.04 \\
\hline Buxus sempervirens & linear & 45.5 & 101.5 & $<0.00001$ & NA & NA \\
\hline Carpinus orientalis & quadratic & 8.5 & 21.3 & $<0.00001$ & 55.47 & 15.52 \\
\hline Corylus avellana & linear & 62.6 & 6.0 & 0.01971 & NA & NA \\
\hline Malus sylvestris & quadratic & 47.8 & 3.9 & 0.0254 & 19.79 & 1.23 \\
\hline Ostrya carpinifolia & linear & 23.5 & 21.0 & 0.00001 & NA & NA \\
\hline Platanus orientalis & quadratic & 47.8 & 11.8 & 0.00015 & 19.81 & 1.16 \\
\hline Quercus robur & quadratic & 48.3 & 104.0 & $<0.00001$ & 19.6 & 1.22 \\
\hline Salix alba & quadratic & 37.6 & 93.4 & $<0.00001$ & 21.52 & 3.17 \\
\hline Salix caprea & quadratic & 46.8 & 31.4 & $<0.00001$ & 19.74 & 1.14 \\
\hline Ulmus minor & quadratic & 33.7 & 4.9 & 0.0127 & 30.02 & 1.11 \\
\hline
\end{tabular}


Table S2. Results of species response curves of trees for soil parameters.

Resultados de las curvas de respuesta de especies de árboles para parámetros de suelo.

\begin{tabular}{lc}
\hline Predictors & Sand\% \\
Distribution & Poisson \\
Link function & $\log$
\end{tabular}

GLM fitted for 25 response variables:

\begin{tabular}{|c|c|c|c|c|c|c|}
\hline Response & Type & $\mathrm{R} 2[\%]$ & $\mathrm{F}$ & $P$ & Optimum & Tolerance \\
\hline Abies bornmuelleriana & quadratic & 20.3 & 262.6 & $<0.00001$ & NA & NA \\
\hline Acer campestre & quadratic & 25.9 & 20.0 & $<0.00001$ & NA & NA \\
\hline Acer platanoides & linear & 7.8 & 7.6 & 0.00671 & NA & NA \\
\hline Carpinus betulus & quadratic & 2.5 & 29.4 & $<0.00001$ & NA & NA \\
\hline Castanea sativa & quadratic & 13.4 & 130.6 & $<0.00001$ & 29.72 & 13.3 \\
\hline Fagus orientalis & quadratic & 8.9 & 226.0 & $<0.00001$ & NA & NA \\
\hline Fraxinus angustifolia & linear & 8.9 & 7.0 & 0.00948 & NA & NA \\
\hline Fraxinus excelsior & linear & 13.6 & 17.7 & 0.00005 & NA & NA \\
\hline Pinus brutia & quadratic & 21.7 & 19.2 & $<0.00001$ & 31.84 & 4.93 \\
\hline Pinus nigra & quadratic & 32.1 & 231.4 & $<0.00001$ & NA & NA \\
\hline Pinus pinaster & quadratic & 76.6 & 11.0 & 0.00159 & 63.89 & 0.426 \\
\hline Populus tremula & quadratic & 25.6 & 157.7 & $<0.00001$ & 39.96 & 5.8 \\
\hline Quercus petraea & quadratic & 17.8 & 184.0 & $<0.00001$ & 37.75 & 10.32 \\
\hline Acer trautvetteri & quadratic & 66.4 & 6.4 & 0.01889 & 50.46 & 0.628 \\
\hline Alnus glutinosa & quadratic & 6.0 & 7.1 & 0.00118 & 56.95 & 16.65 \\
\hline Buxus sempervirens & quadratic & 15.0 & 16.7 & $<0.00001$ & NA & NA \\
\hline Carpinus orientalis & quadratic & 28.5 & 71.9 & $<0.00001$ & 44.36 & 6.22 \\
\hline Malus sylvestris & quadratic & 47.5 & 3.9 & 0.02351 & 44.6 & 3.13 \\
\hline Ostrya carpinifolia & quadratic & 27.3 & 12.2 & 0.00001 & 48.94 & 7.59 \\
\hline Platanus orientalis & quadratic & 47.5 & 11.7 & 0.00003 & 44.6 & 3.13 \\
\hline Quercus robur & linear & 36.7 & 158.0 & $<0.00001$ & NA & NA \\
\hline Salix alba & quadratic & 44.9 & 111.6 & $<0.00001$ & 44.55 & 4.07 \\
\hline Salix caprea & linear & 21.1 & 28.4 & $<0.00001$ & NA & NA \\
\hline Sorbus aucuparia & linear & 24.3 & 7.3 & 0.0079 & NA & NA \\
\hline Ulmus glabra & quadratic & 23.9 & 6.5 & 0.00207 & NA & NA \\
\hline Predictors & Dust $\%$ & & & & & \\
\hline Distribution & Poisson & & & & & \\
\hline Link function & $\log$ & & & & & \\
\hline \multicolumn{7}{|c|}{ GLM fitted for 25 response variables: } \\
\hline Response & Type & $\mathrm{R} 2[\%]$ & $\mathrm{F}$ & $P$ & Optimum & Tolerance \\
\hline Abies bornmuelleriana & quadratic & 5.0 & 64.0 & $<0.00001$ & 26.87 & 15.53 \\
\hline Acer campestre & quadratic & 22.3 & 17.2 & $<0.00001$ & $? ?$ & $? ?$ \\
\hline Acer platanoides & linear & 5.1 & 5.0 & 0.02784 & NA & NA \\
\hline
\end{tabular}


Table S2 Continued

\begin{tabular}{|c|c|c|c|c|c|c|}
\hline Carpinus betulus & linear & 3.3 & 78.8 & $<0.00001$ & NA & NA \\
\hline Castanea sativa & quadratic & 27.6 & 269.1 & $<0.00001$ & NA & NA \\
\hline Fagus orientalis & quadratic & 6.0 & 152.5 & $<0.00001$ & NA & NA \\
\hline Fraxinus angustifolia & linear & 8.4 & 6.6 & 0.01165 & NA & NA \\
\hline Fraxinus excelsior & quadratic & 8.7 & 5.6 & 0.00468 & 41.59 & 9.46 \\
\hline Pinus brutia & quadratic & 19.6 & 17.3 & $<0.00001$ & 40.01 & 6.02 \\
\hline Pinus nigra & quadratic & 36.8 & 265.7 & $<0.00001$ & NA & NA \\
\hline Pinus pinaster & quadratic & 63.1 & 9.1 & 0.00087 & 18.31 & 0.213 \\
\hline Populus alba & linear & 5.5 & 8.0 & 0.00551 & NA & NA \\
\hline Populus tremula & quadratic & 15 & 92.6 & $<0.00001$ & 37.36 & 7.29 \\
\hline Quercus petraea & quadratic & 16.5 & 170.6 & $<0.00001$ & 44.68 & 9.91 \\
\hline Tilia tomentosa & quadratic & 10.3 & 9.3 & 0.00018 & NA & NA \\
\hline Acer trautvetteri & quadratic & 66.3 & 6.4 & 0.01463 & 31.2 & 0.271 \\
\hline Alnus glutinosa & linear & 3.2 & 7.8 & 0.00611 & NA & NA \\
\hline Carpinus orientalis & quadratic & 52.1 & 131.4 & $<0.00001$ & 31.59 & 2.1 \\
\hline Ostrya carpinifolia & quadratic & 6.9 & 3.1 & 0.04873 & 30.96 & 9.76 \\
\hline Platanus orientalis & quadratic & 30.7 & 7.6 & 0.00082 & 31.68 & 4.03 \\
\hline Quercus robur & quadratic & 60.9 & 131.0 & $<0.00001$ & NA & NA \\
\hline Salix alba & quadratic & 44.9 & 111.6 & $<0.00001$ & 31.39 & 2.56 \\
\hline Salix caprea & linear & 23.3 & 31.2 & $<0.00001$ & NA & NA \\
\hline Sorbus aucuparia & quadratic & 34.6 & 5.2 & 0.00861 & 23.08 & 1.79 \\
\hline Ulmus glabra & quadratic & 28.3 & 7.7 & 0.00071 & NA & NA \\
\hline Predictors & $\mathrm{pH}$ & & & & & \\
\hline Distribution & Poisson & & & & & \\
\hline Link function & $\log$ & & & & & \\
\hline \multicolumn{7}{|c|}{ GLM fitted for 23 response variables: } \\
\hline Response & Type & $\mathrm{R} 2[\%]$ & $\mathrm{F}$ & $P$ & Optimum & Tolerance \\
\hline Abies bornmuelleriana & quadratic & 17.4 & 224.6 & $<0.00001$ & 7.19 & 0.519 \\
\hline Acer campestre & quadratic & 29.3 & 22.6 & $<0.00001$ & 6.99 & 0.255 \\
\hline Castanea sativa & quadratic & 63.3 & 616.4 & $<0.00001$ & 5.71 & 0.116 \\
\hline Fagus orientalis & quadratic & 7.8 & 197.4 & $<0.00001$ & 5.97 & 1.19 \\
\hline Pinus brutia & quadratic & 43.4 & 38.3 & $<0.00001$ & NA & NA \\
\hline Pinus nigra & quadratic & 4.8 & 34.6 & $<0.00001$ & NA & NA \\
\hline Pinus pinaster & quadratic & 42.2 & 6.1 & 0.00442 & 5.92 & 0.097 \\
\hline Pinus sylvestris & linear & 29.3 & 7.3 & 0.00788 & NA & NA \\
\hline Populus alba & linear & 23.2 & 33.6 & $<0.00001$ & NA & NA \\
\hline Populus tremula & quadratic & 21.5 & 132.1 & $<0.00001$ & 6.16 & 0.462 \\
\hline Quercus petraea & linear & 18.9 & 392.4 & $<0.00001$ & NA & NA \\
\hline Sorbus torminalis & quadratic & 0.1 & 0.02464 & 0.97567 & NA & NA \\
\hline
\end{tabular}


Table S2 Continued

\begin{tabular}{|c|c|c|c|c|c|c|}
\hline Tilia tomentosa & quadratic & 31.6 & 28.4 & $<0.00001$ & 5.75 & 0.112 \\
\hline Acer trautvetteri & quadratic & 56.6 & 5.4 & 0.00855 & 7.82 & 0.052 \\
\hline Alnus glutinosa & quadratic & 19.8 & 23.8 & $<0.00001$ & 6.46 & 0.416 \\
\hline Buxus sempervirens & quadratic & 37.7 & 42.0 & $<0.00001$ & 7.08 & 0.055 \\
\hline Carpinus orientalis & quadratic & 9.2 & 23.1 & $<0.00001$ & 6.87 & 0.534 \\
\hline Ostrya carpinifolia & quadratic & 13.4 & 6.0 & 0.00332 & NA & NA \\
\hline Quercus robur & quadratic & 43.4 & 93.5 & $<0.00001$ & 6.87 & 0.152 \\
\hline Salix alba & quadratic & 11.7 & 29.1 & $<0.00001$ & 6.88 & 0.451 \\
\hline Salix caprea & quadratic & 34.5 & 23.2 & $<0.00001$ & 6.85 & 0.196 \\
\hline Sorbus aucuparia & quadratic & 32.5 & 4.9 & 0.00921 & 7 & 0.206 \\
\hline Ulmus minor & quadratic & 56.6 & 8.1 & 0.00179 & 6.35 & 0.047 \\
\hline Predictors & EC & & & & & \\
\hline Distribution & Poisson & & & & & \\
\hline Link function & $\log$ & & & & & \\
\hline \multicolumn{7}{|c|}{ GLM fitted for 10 response variables: } \\
\hline Response & Type & $\mathrm{R} 2[\%]$ & $\mathrm{F}$ & $P$ & Optimum & Tolerance \\
\hline Abies bornmuelleriana & quadratic & 44.8 & 578.3 & $<0.00001$ & NA & NA \\
\hline Carpinus betulus & quadratic & 5.1 & 60.2 & $<0.00001$ & NA & NA \\
\hline Castanea sativa & quadratic & 63.3 & 616.4 & $<0.00001$ & 139.36 & 9.17 \\
\hline Fagus orientalis & quadratic & 11.2 & 283.8 & $<0.00001$ & NA & NA \\
\hline Pinus brutia & quadratic & 8.7 & 7.7 & 0.00075 & NA & NA \\
\hline Pinus nigra & quadratic & 38.6 & 278.8 & $<0.00001$ & NA & NA \\
\hline Quercus petraea & quadratic & 53.0 & 549.1 & $<0.00001$ & NA & NA \\
\hline Platanus orientalis & quadratic & 57.4 & 14.1 & 0.00001 & 167.06 & 6.74 \\
\hline Quercus robur & quadratic & 23.2 & 50.1 & $<0.00001$ & 305.03 & 45.23 \\
\hline Salix alba & quadratic & 56.8 & 141.0 & $<0.00001$ & 171.34 & 11.28 \\
\hline
\end{tabular}


